\title{
Calf management practices in dairy animals of rural and urban area under milk shed of South Gujarat
}

\author{
V. S. PRAJAPATI, R. R. SINGH, N. B. JADAV, P. S. SHARMA AND S. V. UNDHAD
}

\begin{abstract}
A field study was conducted to collect the information on calf management practices followed by the dairy animal owners of Navsari district of South Gujarat. Two hundred respondents of 10 villages having elite dairy animals were included in the study. Majority of respondents (97.67\%) of Navsari district attended calving and took care of the calves after parturition while only 2.33 per cent of the respondents didn't do so. Barring 3.5 per cent of the respondents of rural area all others in rural as well as in urban areas attended calving and took care of the calves after the parturition. It was found that majority of the (83\%) respondents cleaned the calf soon after calving and remaining 17 per cent of the farmers didn't followed this practice. The practice of cleaning of the calves just after calving was practiced by 74.5 per cent of the rural and all respondents of the urban areas.Around 40.5 per cent of rural and 61 per cent of the urban respondents allowed the calves to suckle their dams before expulsion of placenta whereas 59.5 (rural) and 39 (urban) per cent of respondents allowed the calves to suckle their dams only after the expulsion of placenta.
\end{abstract}

KEY WORDS : Calf management practices, Rural, Urban area

HOW TO CITE THIS PAPER : Prajapati, V.S., Singh, R.R., Jadav, N.B., Sharma, P.S. and Undhad, S.V. (2017). Calf management practices in dairy animals of rural and urban area under milk shed of South Gujarat. Res. J. Animal Hus. \& Dairy Sci., 8(2) : 99-102 : DOI: 10.15740/HAS/ RJAHDS/8.2/99-102.

Address for correspondence :

V.S. Prajapati, Krishi Vigyan Kendra (J.A.U.), Pipalia, Dhoraji, RAJKOT (GUJARAT) INDIA

Email : drvijay87@gmail.com

Associated Authors':

R.R. Singh, N.B. Jadav, P.S. Sharma and S.V. Undhad, Krishi Vigyan Kendra (J.A.U.), Pipalia, Dhoraji, RAJKOT (GUJARAT) INDIA

Email : drexplicit@gmail.com; nb_jadav@yahoo.com; pinkisharma@jau.in; undhadsv@gmail.com 